\title{
Biosurfactant Production by Cunninghamella phaeosphora UCP 1303 Using Controlled Temperature Through of Arduino
}

\author{
Amanda B. Lins', Ana P. Bione ${ }^{1}$, Tainã C.S. Fonseca ${ }^{1}$, Thaís C. Silva ${ }^{2}$, Paulo H. da Silva ${ }^{2}$, \\ Kyriale V. Morant ${ }^{3}$, Rosileide F.S. Andrade ${ }^{4}$ and Galba M. Campos-Takaki ${ }^{*}$ \\ ${ }^{1}$ Enviromental Process Development, Catholic University of Pernambuco, \\ 50.050-900 Recife, PE, Brazil \\ ${ }^{2}$ Chemical Engineering, Catholic University of Pernambuco, 50.050-900 Recife, PE, Brazil \\ ${ }^{3}$ Chemical Engineering, São Paulo University (USP), 05508-900 São Paulo, SP, Brazil \\ ${ }^{4}$ National Postdoctoral Program (PNPD-CAPES) - Postgraduate Programm in Development of \\ Environmental Processes, Catholic University of Pernambuco, Recife, PE, Brazil \\ ${ }^{5}$ Nucleus of Research in Environmental Sciences and Biotechnology, Catholic University of \\ Pernambuco, 50.050-590 Recife, PE, Brazil
}

*Corresponding author

\section{A B S T R A C T}

\begin{tabular}{|l|}
\hline Ke y w o r d s \\
Soybean oil, Corn \\
steep liqueur, \\
Agroindustrial \\
wastes, Arduino, \\
DS18B20 sensor.
\end{tabular}

The objective of this study was to investigate the ability of Cunninghamella phaeosphora UCP 1303 to produce biosurfactant converting soybean oil and corn liqueur, using temperature monitoring through the Arduino and DS18B20 waterproof temperature sensor. Initially, a $10^{7}$ cells/mL suspension was inoculated and incubated under $150 \mathrm{rpm}$ shaking at 25,28 and $35^{\circ} \mathrm{C}$ during $96 \mathrm{~h}$. Surface and interfacial tensions were determined by the Du Nouyring method and also the emulsification index and the dispersion test in water. The results demonstrated unprecedented use of Arduino in fermentation temperature control, with temperatures of $25^{\circ} \mathrm{C}$ and $35^{\circ} \mathrm{C}$ showing a surface tension reduction of $70 \mathrm{mN} / \mathrm{m}$ to $36.1 \mathrm{mN} / \mathrm{m}$ and $70 \mathrm{mN} / \mathrm{m}$ for $37.1 \mathrm{mN} / \mathrm{m}$ respectively. Fermentation temperature at $28^{\circ} \mathrm{C}$ presented the best results for reducing surface tension $(70 \mathrm{mN} / \mathrm{m}$ to $28.1 \mathrm{mN} / \mathrm{m})$ and interfacial tension $(2.2 \mathrm{mN} / \mathrm{m})$ with high potential of motor oil emulsion Burned $\left(\mathrm{E}_{24}=\right.$ $100 \%)$ and excellent dispersant properties $\left(28.26 \mathrm{~cm}^{2}\right)$ of motor oil burnt in water. The results showed that $\mathrm{C}$. phaeospora produced biosurfactant in low cost medium using agroindustrial residues; in addition, the excellent properties of the biosurfactant suggest its potential of application in the bioremediation of sites polluted by hydrophobic compounds.

\section{Introduction}

Biosurfactants, also known as microbial surfactants, are amphipathic molecules having a hydrophobic (non-polar) and other polar hydrophilic region. Used mainly in the cleaning products industries, such as soaps and detergents, petroleum, cosmetics and hygiene products (Nitschke and Pastore, 2002). Due to its structure, surfactants have several properties, such as reduction of surface and interfacial tension, high emulsifying capacity, dispersant among others. However, because they originate from 
petroleum, they have high toxicity. In this context, the biosurfactants have the same properties, are non-toxic and are produced by microorganisms (bacteria, yeasts and filamentous fungi, these being less exploited), from renewable substrates (Barros et al., 2008; Colla et al., 2012).

Cunninghamela is filamentous fungus that is being used for the production of biosurfactants because it has the ability to metabolize xenobiotic compounds; in response to these, the hydrolases enzymes are excreted. This capability reflects its potential in processes of biodegradation, bioremediation and biotransformation (Eustáquio et al., 2003)

The biosurfactants can be used in the bioremediation, being used in the degradation of hydrocarbons in water through its capacity of emulsion and dispersion in biodegradation of pesticides, to emulsify and increase the solubility of hydrophobic contaminants in soil and water (Nitscheke and Pastore, 2002), in the removal of heavy metals such as uranium, cadmium and lead (Mulligan et al., 2001).

The objective of this study was to produce biosurfactant through Cunninghamella phaeosphora UCP 1303 converting agroindustrial wastes (soybean oil and corn liqueur) digitally monitoring the temperature by the Arduino.

\section{Materials and Methods}

\section{Microorganism and Maintenance media}

Filamentous fungi was used Cunninghamella phaeospora (UCP1303), isolated from the Caatinga of the State of Pernambuco and deposited in the Collection of Cultures UCP (Catholic University of Pernambuco).The strain was maintained in Potato Dextrose Agar medium at $5^{\circ} \mathrm{C}$.

\section{Biosurfactant production medium}

The production medium used consisted of a base of salts $\left(\mathrm{NH}_{4} \mathrm{NO}_{3}-0,1 \mathrm{~g} ; \mathrm{KH}_{2} \mathrm{PO}_{4}\right.$ $0,02 \mathrm{~g} ; \mathrm{MgSO}_{4} .7 \mathrm{H}_{2} \mathrm{O}-0,02 \mathrm{~g}$ and glutamic acid - 1g) supplemented with $6 \%(\mathrm{v} / \mathrm{v})$ of cornflower (CSL) and 2,5\% (v/v) of post-fry soybean oil (SHOW), optimized through factorial planning DCCR $2^{2}$ by Lins et al., (2016).

\section{Substrates for the means of production}

The post-fry soybean oil (SWO) yielded by the informal trade and maize (CSL) residue obtained from corn processing yielded by Corn Products Brasil, both locate in the state of Pernambuco, were used as substrates in the medium for the production of biosurfactant.

\section{Production of biosurfactant}

\section{Inoculum}

The spores of $C$. phaeospora were collected and counted in a Neubauer chamber for a suspension of $10^{7}$. Subsequently, $2 \mathrm{ml}$ of the spore suspension was transferred to the surface of the Sabouraud medium in the Petri dishes, kept at $28^{\circ} \mathrm{C}$ for $24 \mathrm{~h}$, and then 10 discs were cut and transferred to Erlenmayer flasks containing the production medium, incubated at $150 \mathrm{rpm}$, temperatures of $25^{\circ} \mathrm{C}, 28^{\circ} \mathrm{C}$ and $35^{\circ} \mathrm{C}$ for $96 \mathrm{~h}$.

\section{Temperature and $\mathrm{pH}$ determination}

The temperature was determined by the DS18B20 sensor with the aid of Arduino Uno every $10 \mathrm{~min}$. In the fermentation with temperature at $25^{\circ} \mathrm{C}$ the power supply was a 5 $\mathrm{V}$ charger and a microSD card was used to store the data and in the fermentation with temperature at $35^{\circ} \mathrm{C}$ was used a computer with power supply and storage. Two libraries were added to the Arduino software, One 
Wire and Dallas Temperature. These two libraries worked together to extract the data from the DS18B20 waterproof temperature sensor. The DS18B20 sensor can perform temperature readings in a range from $-50^{\circ} \mathrm{C}$ to $125^{\circ} \mathrm{C}$ with an accuracy up to $\pm 0.5^{\circ} \mathrm{C}$ and send the information to the microcontroller using only one wire. Each sensor has a physical address (identified by the OneWire library), so it was possible to place several sensors on a single bus, using a single microcontroller port (Thomsen, 2015). The $\mathrm{pH}$ adjustment to 5.5 was determined by potentiometry.

\section{Separation of metabolic fluid}

After the incubation time, the vials were withdrawn from orbital shaking. The metabolic liquid was separated from the biomass through 120 mesh nylon filtration. Samples were centrifuged at $4000 \mathrm{rpm}$ at $10^{\circ} \mathrm{C}$ for $15 \mathrm{~min}$ and the cell free supernatant was stored for future analyzes.

\section{Biosurfactant potential evaluation tests}

Determination of surface and interfacial tension

The monitoring of the biosurfactant production in the metabolic liquid was performed by measuring the surface and interfacial tension in the $\mathrm{Du}$ Nuoy ring method using the automated tensiometer, according to the methodology of Kuykina et al., (2001). The interfacial tension was evaluated after the addition of n-hexadecane in the supernatant according to Darvishi et al., (2011).

\section{Emulsification Index (IE)}

In the test tubes, $1 \mathrm{~mL}$ of the cell free metabolic liquid and $1 \mathrm{~mL}$ of the different oils were added: vegetal (Oil of Mamona and Maize Oil) and two oils derived from petroleum (Diesel Oil and Burnt Engine Oil). The tubes were vortexed for $2 \mathrm{~min}$ at full speed and allowed to stand for 24 hours according to Cooper and Goldenberg (1987). The percentage emulsification was determined from Equation 1 below.

$\mathrm{E}=\frac{\text { height of the emulsified layer(cm) }}{\text { total height of the liquid }(\mathrm{cm}) \quad \mathrm{X}} \quad 100$ Equation 1

\section{Absorption capacity of biosurfactant}

The dispersion capacity of motor burned oil in water by the biosurfactant was investigated. To this end, $20 \mathrm{~mL}$ of distilled water was contaminated with $0.5 \mathrm{~mL}$ of burned engine oil and $1 \mathrm{~mL}$ of cell-free metabolic fluid was added. The diameter of the free zone formed after the addition of the biosurfactantcontaining metabolic liquid to indicate the ability to disperse hydrophobic substrates was calculated as an oil displacement area (ODA) according to Morikawa et al., (1993) using equation 2 according to Manocha et al., (1980).

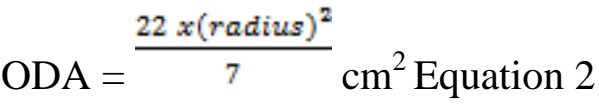

\section{Results and Discussion}

\section{Influence of temperature on the production} of biosurfactant using Arduino

The schedules used by the software with the hardware of the Arduino were efficient, being possible to verify more precisely the temperatures of the shaker in the production of the biosurfactant. No significant temperature variations were observed in the biosurfactant production with a temperature of $25^{\circ} \mathrm{C}$, varying the average hourly temperatures between $25.46^{\circ} \mathrm{C}$ and $25.75^{\circ} \mathrm{C}$, as shown in Figure 1. However, in fermentation with a temperature of $35^{\circ} \mathrm{C}$, occurred significant and distant variations of 
the determined temperature, the average temperatures varied between 35.98 and $39.71^{\circ} \mathrm{C}$ (Figure 2), reaching peaks of $40^{\circ} \mathrm{C}$.

Production of biosurfactant by Cunninghamella phaeosphora in medium containing corncina and soybean oil after frying

According to the results obtained for the production of biosurfactant, in the medium constituted by $2.5 \%$ of oil and $6 \%$ of corncine, in the condition of fermentation at $28^{\circ} \mathrm{C}$ there was the maximum reduction of the surface tension of 70 to $28.1 \mathrm{mN}$ and interfacial from 40 to $2.2 \mathrm{mN} / \mathrm{m}$ (Table 1). The biosurfactant produced by $C$. phaeosphora by fermentation at $28^{\circ} \mathrm{C}$ showed excellent results compared to the surface tension obtained by the biosurfactant synthesized by Cunninghamella elegans that was $28.2 \mathrm{mN} / \mathrm{m}$ (SOUZA, 2015).

\section{Emulsifying property}

Some biosurfactants have the ability to form and stabilize emulsions. In addition, biosurfactants with emulsifying properties are those capable of forming emulsions with percentages above 50\% (Willumsen and Karlson, 1996). In this context, the biosurfactant produced by $C$. phaeosphora in the fermentation condition at $28^{\circ} \mathrm{C}$ was able to form a stable emulsion, with $\mathrm{IE}_{24}$ of 93.62\% using as the hydrophobic substrate the motor burned oil (Figure 3).

The biosurfactants obtained in the fermentations at $25^{\circ} \mathrm{C}$ and $35^{\circ} \mathrm{C}$ presented satisfactory indices, $51.9157 \%$ and $54.708 \%$, $53.448 \%$, respectively.

Dispersibility of engine oil burned by the biosurfactant produced by Cunninghamella phaeosphora

The biosurfactant of $C$. phaeosphora produced in the fermentation condition at $28^{\circ} \mathrm{C}$ dispersed $28.26 \mathrm{~cm}^{2}$ of the burned motor oil (Figure 4), presenting a similar result to Silva et al., (2014) which reached a maximum dispersion index of $37.36 \mathrm{~cm}^{2}$, considering that Cunninghamella echinulata was used in the production of the biosurfactant and both occupied the entire region of the plaque.

Fig.1 Variation of the means of the fermentation temperatures of the biosurfactant production process at $25^{\circ} \mathrm{C}$
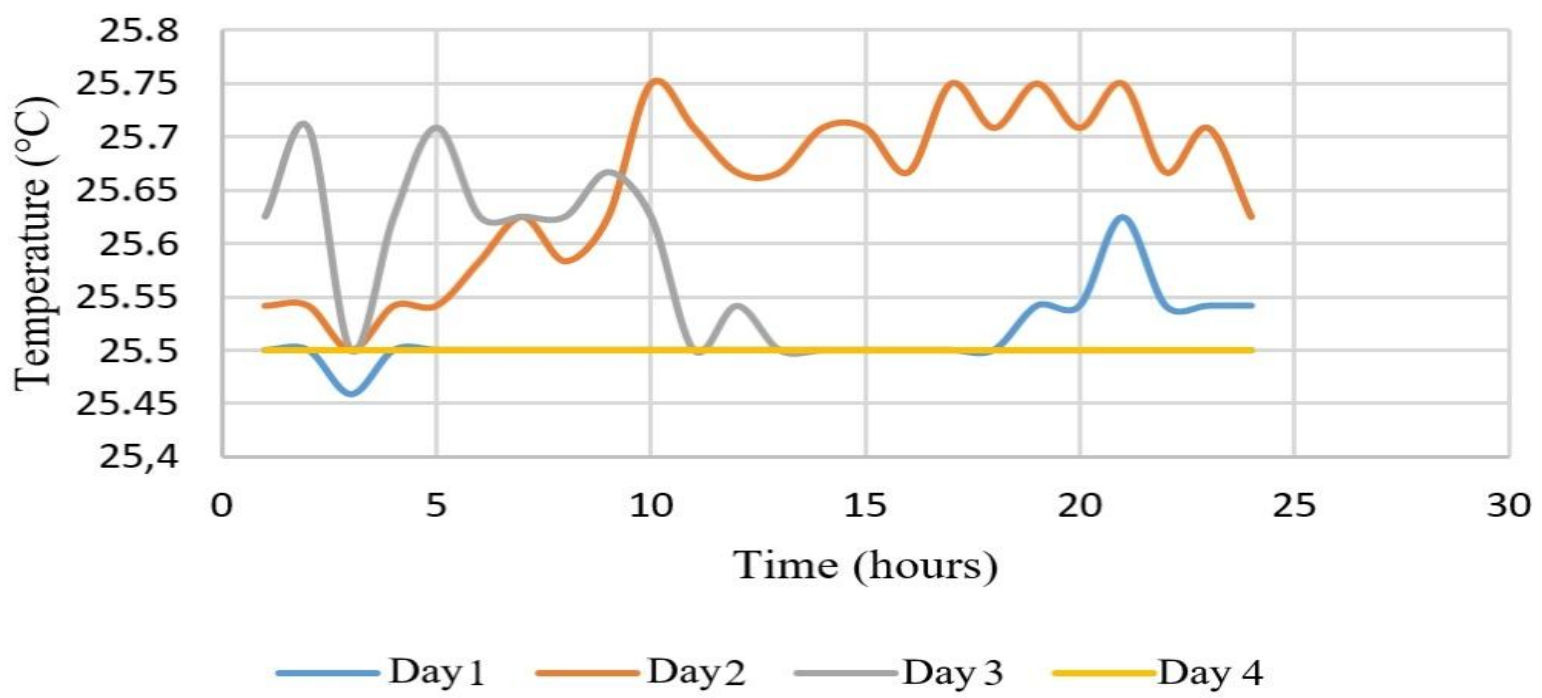
Fig.2 Variation of the means of fermentation temperatures of the biosurfactant production process at $35^{\circ} \mathrm{C}$

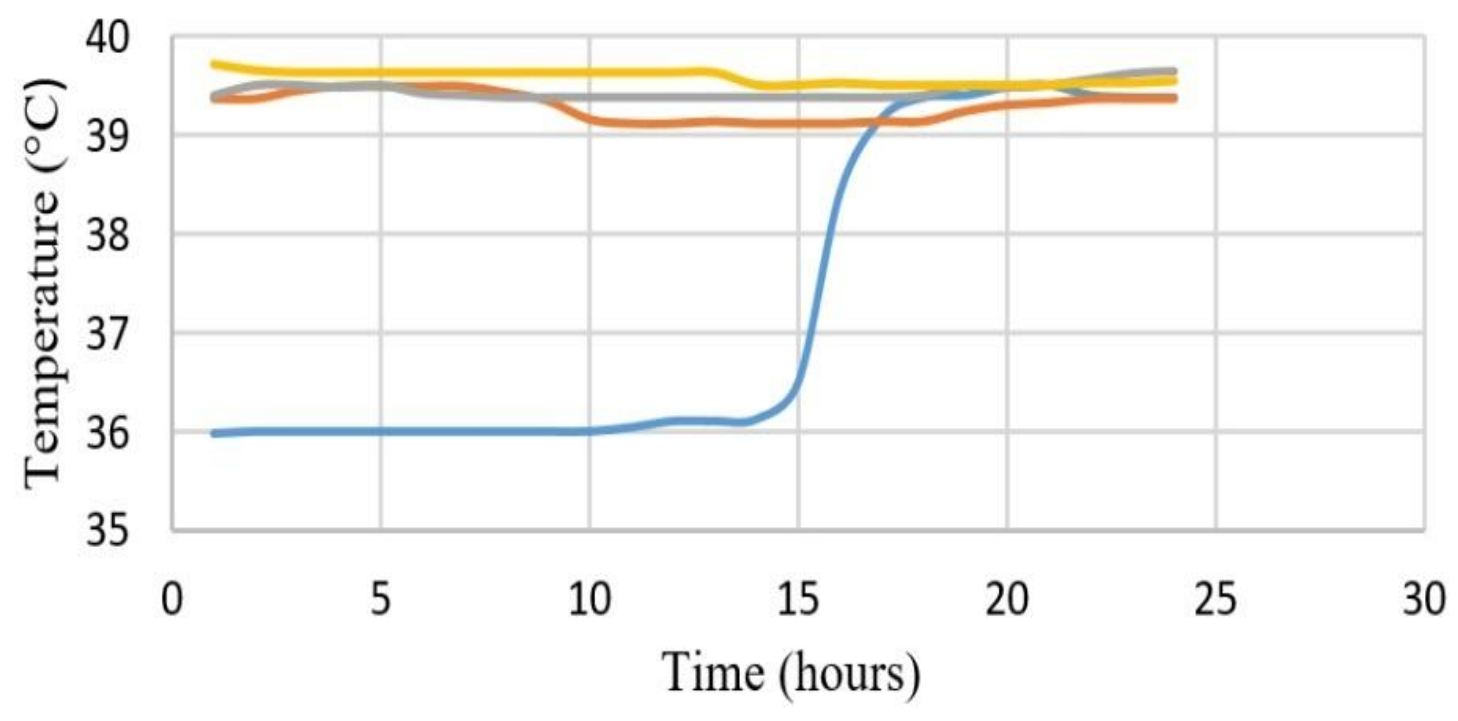

$\longrightarrow$ Day $1-$ Day2 - Day3 Day 4

Fig.3 Determination of the emulsification index $\left(\mathrm{IE}_{24}\right)$ in the metabolic liquid of $C$. phaeosphora using different hydrophobic substrates

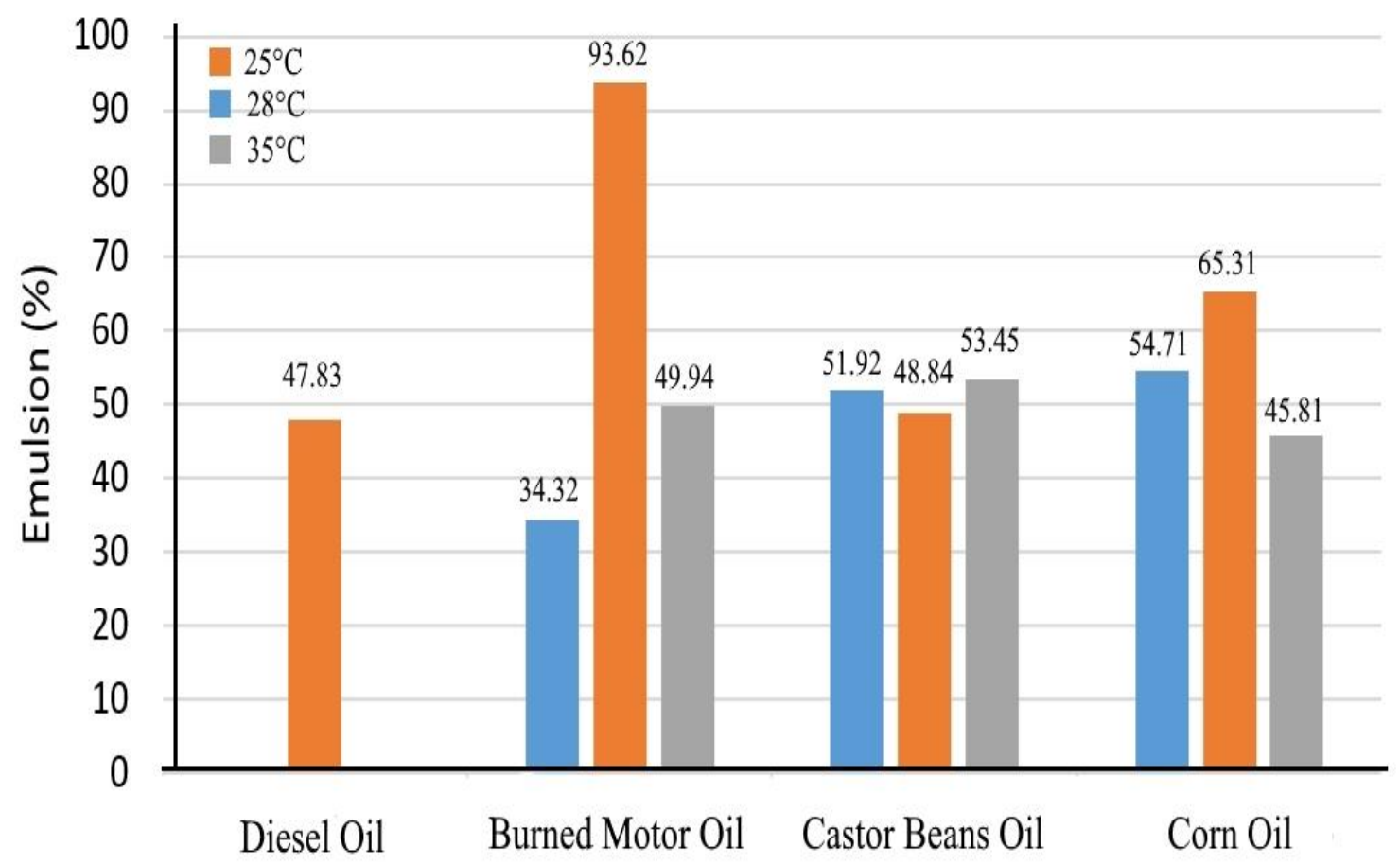


Fig.4 Determination of ODA in the metabolic liquid of $C$. phaeosphora using different hydrophobic substrates

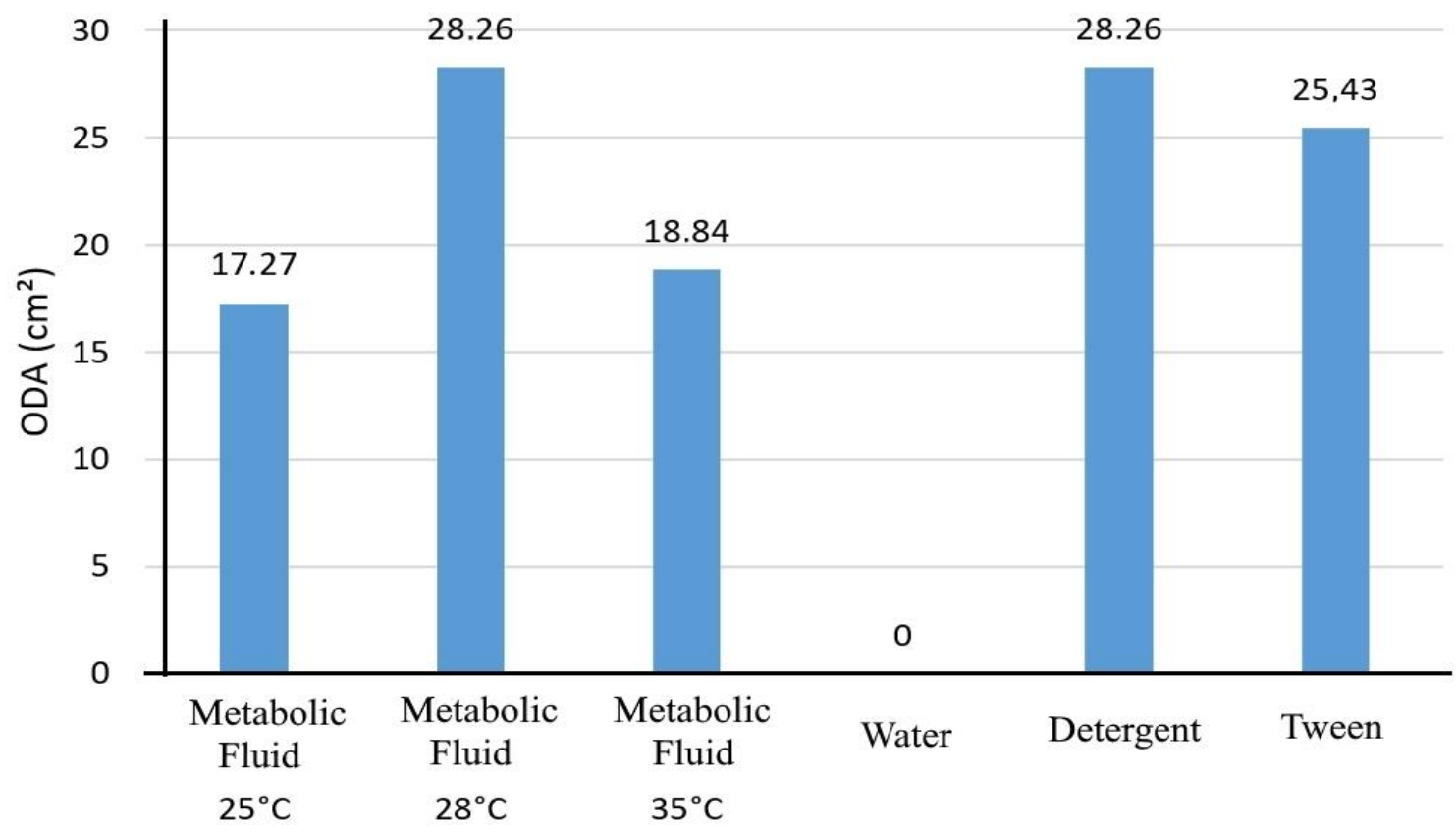

Table.1 Produção de biossurfactante por Cunninghamella phaeospora UCP 1303 determinada através das médias das tensões superficiais no líquido metabólico, após as 96 horas de cultivo

\begin{tabular}{ccc}
\hline Conditions & Average surface tension $(\mathrm{mN} / \mathrm{m})$ & Mean of interfacial tension $(\mathrm{mN} / \mathrm{m})$ \\
\hline $25{ }^{\circ} \mathrm{C}$ & 36.1 & 21.4 \\
$28{ }^{\circ} \mathrm{C}$ & 28.1 & 2.2 \\
$35^{\circ} \mathrm{C}$ & 37.1 & 14.9 \\
\hline
\end{tabular}

At the end, the ability of the microorganism Cunninghamella phaeosphora to metabolize the SWO and CSL substrates of the low cost production medium with the production of biosurfactant (extracellular compound) was verified. It was also possible to evaluate that $28^{\circ} \mathrm{C}$ was the best fermentation temperature for the production of biosurfactant. This biosurfactant that was produced by $C$. phaeospora demonstrated potential of use in industrial applications and bioremediation of petroleum products.

The unprecedented use of programming and arduino in temperature monitoring has been shown to be effective throughout the biosurfactant production process. The
DS18B20 waterproof temperature sensor did not interfere with the process and did not contaminate the microbial cultures.

Finally, the results obtained in this study are promising, their applicability is diverse, either in the use of a system of accurate temperature monitoring, cheap and that does not interfere in the system, or in environmental treatments of ecosystems contaminated with oils, or in industrial processes with the production and commercialization of a natural biosurfactant.

\section{Conflict of Interest}

The authors confirm that this article content has no conflict of interest. 


\section{Acknowledgments}

The authors wish to thank the Brazilian Research Council (CNPq), Brazil, the Coordination for Improvement of Higher Level Education (CAPES), Brazil and the Foundation for Support of Science and Technology of the State of Pernambuco FACEPE, Brazil. Special thanks are given to Catholic University of Pernambuco for making facilities and infrastructure available for the conduct of this research.

\section{References}

Alexandre, V. M. F., Castro, T. M. S., Machado, J., Santiago, V., de Cerqueira, A. C. F. P., Freire, D. andCammarota, M. 2015. Minimização de resíduos sólidos por adição de biossurfactante em sistema de lodos ativados tratando efluente de refinaria de petróleo. Blucher Chemical Engineering Proceedings. 1(2): 7530-7537.

Barros, F. F. C., Quadros, C. P. and Pastore, G. M. 2008. Propriedades emulsificantes e estabilidade do biossurfactante produzido por Bacillussubtilis em manipueira. Ciência e Tecnologia de Alimentos, 28(4): 979985.

Campos, J. M., Stamford, T.L.M. andSarubbo, L. A. 2015. Utilização de biossurfactante como substituto aos emulsificantes sintéticos em maioneses. Blucher Chemical Engineering Proceedings. 1(2): 4948-4955.

Colla, L. M., Hemkemeier, M. and Gil, A. S. L. 2012. Biossorção de cádmio e produção de biossurfactantes por fungos filamentosos em fermentação submersa. Revista CIATEC - UPF. 4, 1-10.

Cooper, D. G., Goldenberg, B. G. 1987. Surface-Active Agents from two Bacillus Species. Applied and Enviromental Microbiology. 53(2): 224-
229.

Darvishi, P., Ayatollahia, S., Mowlaa, D. and Niazi, A. 2011. Biosurfactant production under extreme environmental conditions by an efficient microbial consortium, ERCPPI-2. Journal Colloids and Surfaces B: Biointerfaces. 84, 292-300.

Eustáquio, W. V., Soares, M. R., HIPÓLITO, A. S., Medeiros, E. V., Silva, G. M. C. and Maracaja, P. B. 2003. Caracterização bioquímica e enzimática de Cunninghamella isoladas de manguezal. Revista de biologia e ciências da terra. 3(2).

Goldemberg, J. andLucon, O. 2008. Energia, meio ambiente e desenvolvimento. Estudos avançados. 21(59): 7-20.

http://blog.filipeflop.com/sensores/sensor-detemperatura-ds18b20-arduino.html.

Kuyukina, M.S., Ivshina, I.B., Makarov, S.O., Litvinenko, L.V., Cunningham, C.J. and Philp, J. 2015. Effect of biosurfactants on crude oil desorption and mobilization in a soil system. Environmental international. 3(2): 155161.

Lemos, J., França, I., Santos, B., Melo, V. and Gonçalves, L. 2015. Potencial de aplicação de biosurfactante bacteriano do tipo lipopeptídeo na biorremediação de ambientes contaminados (um espaço). Blucher Chemical Engineering Proceedings. 1(2): 1417-1424.

Lins, A.B., Bione, A.M., Silva, T.C., de Souza, D.G. and Campos-Takaki G.M. 2016. Low-cost production of biosurfactant by Cunninghamella phaeospora using agro-industrial wastes. Microbes in the Spotlight: Recent Progress in the Understanding of Beneficial and Harmful Microorganisms. 1, 339-343.

Manocha, M. S. San-Blas. G., Centeno, S. 1980.Lipid composition of Paracciodioids brasilienses: Possible 
correlation with virulence of different strains. J. Gen. Microbiol. 177, 147154.

Morikawa, M. Daido, H., Takao, T. et al., 1993. A new lipopeptide biosurfactant produced by Arthrobacter sp. strain MIS38. Journal of Bacteriology. 175(20): 6459-6466.

Mulligan, C. N. 2005. Environmental applications for biosurfactants. Environmental pollution. 133, 183-198.

Nitschke, M. and Pastore, G. M. 2002.Biossurfactantes: propriedades e aplicações. Química Nova. 25(5): 772776.

Schenberg, A. C. G. 2010. Biotecnologia e desenvolvimento sustentável. Dossiê Biotecnologia. 24(70).

Soares, A. K. S. N., Souza, R. R. 2016. Utilização de biossurfactante no escoamento de petróleo em campo maduro.Scientia Plena. 12(5).

Souza, D. G. 2015. Produção de quitina, quitosana e biossurfactante por Cunninghamella elegans UCP/WFCC 0542 em meio suplementado com resíduos agroindustriais. MSc. Dissertation,CatholicUniversityof Pernambuco, Recife, Brazil.

Thomsen, A. 2016. Medindo temperatura debaixo d'água com DS18B20.

Velloso, F. Informática: Conceitos Básicos- $9^{\mathrm{a}}$ Edição. Elsevier Brasil, 2014.

Willumsen, Pia A., Karlson, Ulrich. 1996. Screening of bacteria, isolated from PAH-contaminated soils, for production of biosurfactants and bioemulsifiers. Biodegradation. 7(5): 415-423.

\section{How to cite this article:}

Amanda B. Lins, Ana P. Bione, Tainã C.S. Fonseca, Thaís C. Silva, Paulo H. da Silva, Kyriale V. Morant, Rosileide F.S. Andrade and Galba M. Campos-Takaki. 2017. Biosurfactant Production by Cunninghamella phaeosphora UCP 1303 Using Controlled Temperature Through of Arduino. Int.J.Curr.Microbiol.App.Sci. 6(12): 2708-2715.

doi: https://doi.org/10.20546/ijcmas.2017.612.314 